Gut, 1983, 24, 154-157

\title{
Gastro-oesophageal function in normal subjects after oral administration of ranitidine
}

\author{
L WALLIN, ${ }^{*}$ T MADSEN, AND S BOESBY \\ From the Oesophagus Laboratory. Department of Thoracic and Cardiorascular Surgery. Odense University \\ Hospital. Odense. Denmark
}

SUmmary The aim of the study was to investigate gastro-oesophageal function in normal subjects after oral administration of $150 \mathrm{mg}$ ranitidine as a single dose. The study was designed as a double blind crossover investigation. Ten healthy men, aged 26-49 years (median 29 years) joined the study. A series of oesophageal function tests were performed, starting 90 minutes after oral intake of ranitidine or placebo. Gastro-oesophageal sphincter pressure was measured using a perfused catheter system and a continuous pull-through technique. No changes in sphincter pressure could be demonstrated. Peristaltic amplitude in the body of the oesophagus as well as the duration and velocity of the peristalsis were measured after wet swallows (bolus $5 \mathrm{ml}$ of water). We found no changes in these variables. Intragastric $\mathrm{pH}$ was measured and was higher after ranitidine than after placebo $(\mathrm{p}<(0 \cdot()) 5)$. Plasma ranitidine concentration did not correlate with intragastric $\mathrm{pH}$. No effect of ranitidine could be demonstrated on the results of a standard acid clearing test. It is concluded that ranitidine, given orally in sufficient doses to suppress gastric acid secretion. does not influence gastro-oesophageal sphincter pressure or peristaltic activity in the oesophagus of normal subjects.

Ranitidine (substituted aminoalkyl furan) is a new potent histamine $\mathrm{H}_{2}$-receptor blocker. Comparisons with cimetidine have shown ranitidine to be about six times more potent on a molar basis in the inhibition of gastric acid secretion. ${ }^{1-3}$ Oral intake of ranitidine is followed by plasma concentrations high enough to inhibit acid secretion eight hours after administration of the drug.

The possible role of ranitidine in the treatment of patients with acid gastro-oesophageal reflux has not yet been fully established. Before such studies are carried out. it is necessary to clarify the influence of ranitidine on the gastro-oesophageal region. So far, only gastro-oesophageal sphincter pressure has been measured after administration of ranitidine and the results are conflicting. ${ }^{+5}$

The aim of the present study has been to investigate gastro-oesophageal sphincter pressure, oesophageal motility, and clearing efficiency after

\footnotetext{
* Address for reprint requests: Lene Wallin. The Oesophagus Laboratory. Department of Thoracic and Cardiovascular Surgery. Odense Lniversity Hospital. 5()(x) Odense C. Denmark.

Received for publication 10 May 1982
}

oral intake of ranitidine in a dose which is followed by inhibition of gastric acid secretion.

\section{Methods}

SUBJECTS

The subjects were 10 healthy men, aged $26-49$ years (median 29 years). They all gave informed consent.

The study was designed as a double blind crossover study. On separate days the fasting volunteer received either ranitidine $(150 \mathrm{mg})$ or placebo as coded tablets in randomised order. The measurements began 1.5 hours after oral intake of the tablet. When the whole study and reading of the curves had been completed, the code was broken and the results allocated to drug or placebo group for statistical evaluation.

The pressure measurements were carried out using a probe consisting of three perfused polyethylene catheters (Clay Adams, PE 160; internal diameter $1.14 \mathrm{~mm}$, external diameter $1.58 \mathrm{~mm}$ ). One catheter was connected to a cylindrical metal capsule with three side holes at the same level $120^{\circ}$ apart. ${ }^{6}$ The diameter of the side holes was the same 
as the internal diameter of the catheter. The capsule was $1.5 \mathrm{~cm}$ long and had an external diameter of 2.5 $\mathrm{mm}$. The capsule was sealed off just distal to the side holes and via a short length of tubing connected to a metal weight. Open tip catheters were fixed 10 and $15 \mathrm{~cm}$ above the capsule. The catheter connected to the metal capsule was used for sphincter pressure measurements and was perfused by means of a capillary infusion system (Intraflo CFS 30; flow 30) $\mathrm{ml} / \mathrm{h}$ ). The open tip catheters were used for measurements of peristalsis; each catheter was perfused by means of a capillary infusion system (Intraflo CFS 03; flow $3 \mathrm{ml} / \mathrm{h}$ ). External pressure transducers (Siemens Elema 746) were connected and the pressure curves were transcribed on a mingograph (Elema Schonander, EMT 81). The technical characteristics of the pressure measuring system are stated in Table 1.

The pressure probe was introduced transnasally and passed to the stomach and all pressure measurements were carried out with the volunteer in the supine position. Gastro-oesophageal sphincter pressure was measured at end expiration by continuous withdrawal of the probe through the sphincter at a rate of $0.8 \mathrm{~cm} / \mathrm{s}$. An electric motor withdrew the probe. Three measurements of the gastro-oesophageal sphincter pressure were carried out during each experiment.

The probe was then positioned with the metal capsule $5 \mathrm{~cm}$ oral to the sphincter and thus the open tip catheters 15 and $20 \mathrm{~cm}$ oral to the sphincter. After five minutes of rest oesophageal peristalsis was measured in relation to three swallows using a $5 \mathrm{ml}$ bolus of water each time.

The pressure probe was withdrawn and another probe consisting of a $\mathrm{pH}$ electrode (Radiometer GK $282 \mathrm{C})$ and two open tip polyethylene catheters (Clay Adams PE 160) was introduced. The tip of the catheters was fixed just above the $\mathrm{pH}$ electrode and $15 \mathrm{~cm}$ above, respectively. The $\mathrm{pH}$ electrode was connected to a pH-meter (Beckmann Chem$\mathrm{Mate}^{\mathrm{TM}}$ ) and the catheters to pressure registration units as above.

Table 1 Technical characteristics of perfused pressure measurement systems

\begin{tabular}{rllll}
\hline & $\begin{array}{l}\text { Natural } \\
\text { frequency } \\
(\mathrm{Hz})\end{array}$ & $\begin{array}{l}\text { Degree of } \\
\text { damping }\end{array}$ & $\begin{array}{l}\text { Pressure rise } \\
(\mathrm{mmHg} / \mathrm{s})\end{array}$ & $\begin{array}{l}\text { Compliance } \\
(\mu / / 100 \mathrm{mmH})\end{array}$ \\
\hline $\begin{array}{r}\text { Intraflo CFS 03 } \\
\text { with catheter }\end{array}$ & 16.8 & 0.163 & 35 & 2.33 \\
$\begin{array}{r}\text { Intraflo CFS 30 } \\
\text { with catheter }\end{array}$ & 16.8 & 0.24 & 1010 & 0.825 \\
\hline
\end{tabular}

Pressure transducer: Siemens-Elema 746; catheter: $110 \mathrm{~cm}$ Clay Adams PE 160
Intragastric $\mathrm{pH}$ was measured and the probe was withdrawn and positioned with the electrode $5 \mathrm{~cm}$ oral to the sphincter by means of manometric characteristics. An acid clearing test ${ }^{7}$ was then performed. Fifteen $\mathrm{ml}(0 \cdot 1 \mathrm{M} \mathrm{HCl}$ was instilled through the oral catheter and the volunteer swallowed every half minute until oesophageal $\mathrm{pH}$ was above 5 .

Blood samples for measurement of plasma ranitidine concentration were taken by the end of the experiment (120-150 minutes after intake of the tablet).

VARIABLES AND DEFINITIONS

The gastro-oesophageal sphincter pressure is defined as the maximal pressure in sphincter less gastric fundic pressure $(\mathrm{mmHg})$.

Peak peristaltic pressure less mean oesophageal pressure $15 \mathrm{~cm}$ oral to the gastro-oesophageal sphincter was calculated as the peristaltic amplitude $(\mathrm{mmHg})$. Duration of the peristaltic pressure was measured from the beginning of the rise in pressure until the pressure had returned to basal level, expressed in seconds.

The velocity of the peristaltic pressure wave was calculated from the maximal peristaltic pressure registered by the orally placed open tip catheter to the maximal pressure registered by the other open tip catheter expressed in $\mathrm{cm} / \mathrm{s}$. The acid clearing efficiency is expressed as the number of swallows needed to bring $\mathrm{pH}$ above 5 .

STATISTICS

Wilcoxon's test for paired comparisons was used. Spearman's rho was used for test of correlation between intragastric $\mathrm{pH}$ and plasma ranitidine. $\mathrm{P}$ values less than 0.05 were regarded as significant.

\section{Results}

The results are stated in Table 2. Comparing the results obtained after ranitidine with those after placebo no significant differences could be found except with regard to intragastric $\mathrm{pH}$. No correlation was found between intragastric $\mathrm{pH}$ and plasma ranitidine concentration (rho: 0.4182; $\mathrm{p}>0 \cdot 1)$.

\section{Discussion}

We found that oral intake of ranitidine is followed by a rise in intragastric $\mathrm{pH}$, while no change could be shown in gastro-oesophageal sphincter pressure, oesophageal peristalsis, or acid clearing efficiency in normal subjects.

We chose a dose of ranitidine which is recom- 
Table 2 Gastro-oesophageal function and plasma ranitidine concentration in 10 healthy subjects after oral administration of $150 \mathrm{mg}$ ranitidine or placebo tablets

\begin{tabular}{|c|c|c|c|c|c|c|c|}
\hline & $\begin{array}{l}\text { Plasma } \\
\text { concentration } \\
(\mathrm{ng} / \mathrm{ml})\end{array}$ & $\begin{array}{l}\text { Sphincter } \\
\text { pressure } \\
(\mathrm{mmHg})\end{array}$ & $\begin{array}{l}\text { Peristaltic } \\
\text { amplitude } \\
(\mathrm{mmHg})\end{array}$ & $\begin{array}{l}\text { Wave } \\
\text { duration } \\
\text { (s) }\end{array}$ & $\begin{array}{l}\text { Peristaltic } \\
\text { velocity } \\
(\mathrm{cm} / \mathrm{s})\end{array}$ & $\begin{array}{l}\text { Intragastric } \\
p H\end{array}$ & $\begin{array}{l}\text { Acid } \\
\text { clearing } \\
\text { (swallows) }\end{array}$ \\
\hline Placebo & $\begin{array}{l}0 \\
(0-9)\end{array}$ & $\begin{array}{l}13 \\
(3-27)\end{array}$ & $\begin{array}{l}74 \\
(19-118)\end{array}$ & $\begin{array}{l}4 \cdot() \\
(2 \cdot 6-8 \cdot 4)\end{array}$ & $\begin{array}{l}3 \cdot 6 \\
(2 \cdot 6-5 \cdot 6)\end{array}$ & $\begin{array}{l}1 \cdot 0 \\
(0 \cdot 2-2 \cdot(0)\end{array}$ & $\begin{array}{l}13 \\
(5-33)\end{array}$ \\
\hline Ranitidine & $\begin{array}{l}245 \\
(102-72())\end{array}$ & $\begin{array}{l}13 \\
(5-28)\end{array}$ & $\begin{array}{l}65 \\
(18-143)\end{array}$ & $\begin{array}{l}4 \cdot() \\
(2 \cdot 6-6 \cdot())\end{array}$ & $\begin{array}{l}3 \cdot 8 \\
(1 \cdot 8-6 \cdot 3)\end{array}$ & $\begin{array}{l}2 \cdot 6^{*} \\
(0 \cdot 8-6 \cdot 1)\end{array}$ & $\begin{array}{l}17 \\
(8-42)\end{array}$ \\
\hline
\end{tabular}

Results given in median and range. * Significant difference, $\mathrm{p}<0) \cdot(0) 5$

mended for the treatment of patients with duodenal ulcer $^{\circledR}$ and we administered the drug orally. It is well documented that this dose of ranitidine is followed by a rise in intragastric $\mathrm{pH}$ and a reduction of the volume and acidity of gastric acid secretion, ${ }^{1} 289$ both in patients with duodenal ulcer and normal subjects.

Intravenous bolus injection of ranitidine has been shown to increase gastro-oesophageal sphincter pressure in normal subjects. 5 This effect was blocked by atropine, so the effect was thought to be mediated via the cholinergic nervous system. Plasma ranitidine concentration was not measured in that study, so the result might be explained by excessive high peak values of ranitidine.

The effect of continuous infusion of ranitidine on sphincter pressure has been investigated recently ${ }^{+}$ and no change in sphincter pressure was found. Furthermore, the effect of oral ranitidine in a dose of 10() $\mathrm{mg}$ on sphincter pressure was studied, and, as with the results of the present investigation, no change was found. ${ }^{+}$

The effect of continuous infusion of cimetidine on sphincter pressure has been investigated, and no change was found in one study, "' while in the other an increase in sphincter pressure was followed by a decrease." Oral intake of cimetidine does not change sphincter pressure..$^{12}$ Changes in intragastric milieu are followed by changes in gastrooesophageal sphincter pressure ${ }^{9.3}$ and of the competence of the gastro-oesophageal region. ${ }^{\text {It }}$ Thus we would have expected a rise in intragastric $\mathrm{pH}$ after ranitidine to be followed by an increase in sphincter pressure.

This study is the first to elucidate the possible effect of ranitidine on oesophageal motility. The peristaltic amplitude, velocity, and duration was not found to be influenced by ranitidine and. furthermore, the acid clearing efficiency was unchanged.

The studies mentioned have all been carried out using normal volunteers for the investigations. It is possible that treatment with ranitidine of patients with incompetent gastro-oesophageal sphincter is followed by a slight increase in pressure, as is treatment with cimetidine. ${ }^{15} 16$

We wish to thank Glaxo Laboratories for the supplies of ranitidine, coding of the tablets, and for plasma ranitidine measurements.

\section{References}

1 Domschke W, Lux G, Domschke S. Furan $\mathrm{H}_{2}$ antagonist ranitidine inhibits pentagastrin-stimulated gastric secretion stronger than cimetidine. Gastroenterology 1980; 79: 1267-71.

2 Kett K. Aadland E. Berstad A. Inhibition of gastric secretion in man with a new $\mathrm{H}_{2}$-receptor antagonist. ranitidine. Scand J Gastroenterol 1980; 15: 249-51.

3 Sewing K-Fr, Billian A, Malchow H. Comparative study with ranitidine and cimetidine on gastric secretion in normal volunteers. Gut 198(); 21: 75()-2.

4 Denis P. Galmiche JP. Ducrotte P. Colin R. Pasquis P. Lefrancois $R$. Effect of ranitidine on resting pressure and pentagastrin response of human lower oesophageal sphincter. Dig Dis Sci 1981; 26: 999-1(1)2.

5 Bertaccini G. Molina E. Bobbio P. Foggi E. Ranitidine increases lower oesophageal sphincter pressure in man. Ital J (jastroenterol 1981; 13: 149-50.

6 Bocsby S. Brandsborg M. Brandsborg (). Larsen NK. Pedersen SA. The effect of carbachol on resting gastro-oesophageal sphincter pressure and serum gatstrin in normal subjects. Scand J Gastroenterol 1976: 11: $171-5$.

7 Boeshy S. Gastro-oesophageal sphincter pressure. motility and acid clearing. Scand J Gastroenterol 1977: 12: $4(17-16$.

8 Walt RP. Malc P-J. Rawlings J. Hunt RH. MiltonThompson (iJ. Misiewicz JJ. Comparison of the effects of ranitidine. cimetidine and placebo on the 24 hour intragastric acidity and nocturnal acid secretion in patients with duodenal ulcer. (itut 1981: 22: 49-54.

9 Sheers $R$. Roberts $N$. The effect of ranitidine and cimetidine on pentagastrin and insulin stimulated 
gastric secretion. Scand J Gastroenterol 1981; 16: suppl 69, 51-7.

10 Osborne DH, Lennon J, Henderson M, Lidgard G, Creel R, Carter DC. Effect of cimetidine on human lower oesophageal sphincter. Gut 1977; 18: 99-104.

11 Bailey RJ, Sullivan SN, MacDougall BRD, Williams R. Effect of cimetidine on lower oesophageal sphincter. Br Med J 1976; 2: 678.

12 Kravitz JJ, Snape WJ, Cohen S. Effect of histamine and histamine antagonists on human lower oesophageal function. Gastroenterology 1978; 74: 435-40.

13 Castell DO. Harris LD. Hormonal control of gastro- oesophageal-sphincter strength. $N$ Engl J Med 1970; 282: 886-9.

14 Boesby S. Effect of changes in the intragastric milieu on competence of the gastro-oesophageal region. Scand J Gastroenterol 1977; 12: 215-20.

15 Wallin $\mathrm{L}$. The influence of cimetidine on the acid gastro-oesophageal reflux in duodenal ulcer patients. Scand J Gastroenterol 1980; 15: 157-63.

16 Wallin L, Grove O, Nielsen HO. Reflux oesophagitis and cimetidine: evaluation of symptoms, biopsies and acid gastro-oesophageal reflux pattern before and during treatment. Scand J Gastroenterol 1980; 15: 919. 